\title{
Clinical potential of eluxadoline in the treatment of diarrhea-predominant irritable bowel syndrome
}

This article was published in the following Dove Press journal:

Therapeutics and Clinical Risk Management

13 May 2016

Number of times this article has been viewed

\author{
Aleksandra Sobolewska- \\ Włodarczyk' \\ Marcin Włodarczyk' \\ Martin Storr ${ }^{2}$ \\ Jakub Fichna' \\ 'Department of Biochemistry, Faculty \\ of Medicine, Medical University \\ of Lodz, Lodz, Poland; ${ }^{2}$ Center of \\ Endoscopy, Starnberg, Germany
}

\begin{abstract}
Diarrhea-predominant irritable bowel syndrome (IBS-D) belongs to the group of functional gastrointestinal disorders and is characterized by abdominal pain in conjunction with diarrhea. The incidence of IBS-D is currently increasing, leading to a heavy economic burden for patients and health care systems worldwide. Recent studies suggest eluxadoline as an attractive new tool for the treatment of patients with IBS-D. Eluxadoline is an orally active $\mu$ - and $\kappa$-opioid receptor agonist and $\delta$-opioid receptor antagonist, with powerful antidiarrheal and analgesic activity. Eluxadoline is believed to act locally in the enteric nervous system, and has no adverse effects in the central nervous system. In this review, we discuss the most recent findings on the mechanism of action of eluxadoline and the results of the clinical trials in patients with IBS-D. We also discuss possible side effects and analyze the potential of eluxadoline to be used in the treatment of IBS-D.
\end{abstract}

Keywords: abdominal pain, health care, functional gastrointestinal disorders, IBS, constipation, discomfort

\section{Introduction}

Irritable bowel syndrome (IBS) belongs to the group of functional gastrointestinal disorders ${ }^{1}$ which involve visceral hypersensitivity and impaired gastrointestinal motility. ${ }^{1,2}$ IBS affects up to $16 \%-26 \%$ of the world population. ${ }^{3}$ IBS, like other functional gastrointestinal disorders, has no identified organic cause. ${ }^{3-5}$ Recently, Wouters et al reported that mast cell activation has a central pathophysiological role in IBS and possibly in functional dyspepsia. ${ }^{6}$ However, IBS is also known as a disorder of the brain-gut axis. ${ }^{2}$

IBS is characterized by chronic abdominal pain, discomfort, bloating, and alteration of bowel habits. Diarrhea and constipation may predominate, or they may alternate; accordingly, IBS can be classified as diarrhea predominant (IBS-D), constipation predominant, with alternating stool pattern, or pain predominant. ${ }^{7}$ In some individuals, IBS may have an acute onset and develop after an infectious disease characterized by two or more of the following: fever, vomiting, diarrhea, or positive stool culture. Consequently, this postinfectious state has been termed "postinfectious IBS".,

Diagnosis of IBS is complex and principally symptom based, and no specific laboratory or imaging test can be performed for a positive diagnosis of IBS. IBS diagnosis involves principally excluding other conditions, such as inflammatory bowel diseases or celiac disease, and then following the procedure to categorize the patient's symptoms. Ruling out parasitic infections, lactose intolerance, small-intestinal 
bacterial overgrowth, and celiac disease is, depending on the patient's symptoms, necessary. In patients over 50 years of age, a screening colonoscopy is recommended. ${ }^{9}$ Noteworthy, IBS sufferers are at an increased risk of surgeries, such as appendectomy, cholecystectomy, and hysterectomy, in some cases due to IBS symptoms being misdiagnosed as other medical conditions. ${ }^{10}$

Nowadays, there are no specific lab tests to diagnose IBS. Recently, an interesting study was published by Dothel et al who analyzed mucosal biopsy samples collected from patients with IBS and asymptomatic healthy individuals. ${ }^{11}$ Furthermore, neuronal-specific enolase, growth-associated protein 43 (GAP43), NGF, and NTRK1 were localized and quantified by immunohistochemistry and enzyme-linked immunosorbent assay, respectively. The study showed that nerve fiber density and sprouting, as well as expression of NGF and NTRK1, are significantly increased in mucosal tissues of patients with IBS. This result may suggest that alterations of cellularity in colonic biopsies may be helpful in IBS diagnosis. ${ }^{11}$

IBS is one of the most common diagnoses in primary care and gastroenterology practice. ${ }^{12}$ Nevertheless, the treatment options for IBS, especially for IBS-D, are limited and frequently unsuccessful. Initial therapy includes dietary and lifestyle modifications, but in most patients, these are ineffective. There are some studies showing rifaximin and aldosterone as potential in the treatment of IBS; ${ }^{13,14}$ however, the latter has been approved only for women. ${ }^{14}$

The potential of rifaximin in IBS treatment was observed in two identically designed, double-blind, placebocontrolled trials (TARGET 1 and TARGET 2). ${ }^{14}$ In these studies, 1,260 patients with IBS without constipation were randomized to receive either rifaximin $550 \mathrm{mg}$ or placebo, three times daily for 2 weeks, and were followed up for 10 weeks. The relief from global IBS symptoms during the first 4 weeks after treatment was significantly higher in patients who received rifaximin than placebo. ${ }^{14}$

Because of such a narrow choice, new therapeutics for IBS-D are urgently needed.

\section{Eluxadoline in IBS-D}

Eluxadoline (5-(\{[(2S)-2-amino-3-(4-carbamoyl-2,6dimethylphenyl)propanoyl][(1S)-1-(4-phenyl-1H-imidazol2-yl)ethyl]amino methyl)-2-methoxybenzoic acid; Figure 1) is a novel, orally active drug for the treatment of diarrhea and abdominal pain in individuals with IBS-D. It was approved for use by the US Food and Drug Administration on May 27, 2015. ${ }^{11}$

Eluxadoline is a $\mu$ - and $\kappa$-opioid receptor agonist and $\delta$-opioid receptor antagonist that acts locally in the enteric

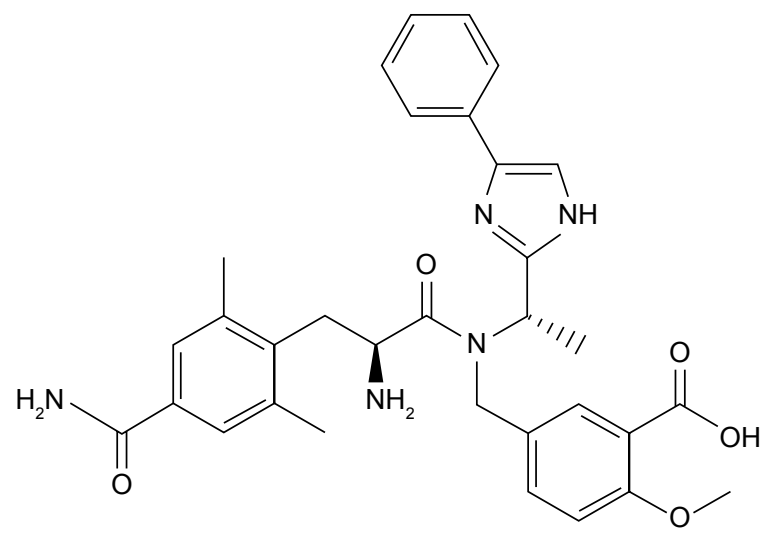

Figure I Eluxadoline (5-(\{[(2S)-2-amino-3-(4-carbamoyl-2,6-dimethylphenyl) propanoyl][(IS)-I-(4-phenyl-I H-imidazol-2-yl)ethyl]amino\}methyl)-2methoxybenzoic acid).

nervous system, and with possibly negligible adverse effects in the central nervous system. ${ }^{15,16}$ Activation of the $\mu$-opioid receptor causes analgesia, sedation, slightly reduced blood pressure, itching, nausea, euphoria, decreased respiration, and miosis (constricted pupils). ${ }^{17-19}$ In the gastrointestinal tract, the $\mu$-opioid receptor agonists have long been known to slow motility, decrease visceral sensation, and inhibit secretion. ${ }^{20}$ The additional function of eluxadoline, as a $\delta$-opioid receptor antagonist, reduces some of the undesired $\mu$-opioid effects, such as excessive slowing of motility as well as enhancing of $\mu$ - and $\kappa$-opioid receptor-mediated effects on visceral sensation. ${ }^{21-23}$

Endogenous opioid system consists of $\mu-, \kappa-$, and $\delta$-opioid receptors. Their endogenous ligands, namely Met-enkephalin, Leu-enkephalin, $\beta$-endorphin, and dynorphin, can be found in the gut, both in neurons and endocrine cells. When released, these ligands activate the opioid receptors and influence the enteric circuitry controlling motility and secretion. Inhibition of gastric emptying, increase in sphincter tone, induction of stationary motor patterns, and blockade of peristalsis ensue are the result of opioid receptors activation. Consequently, the most frequent and troublesome adverse reaction of opioid analgesic therapy is constipation. ${ }^{24}$

Viscerosensory nerve sensitivity and symptoms in IBS are connected to alterations in the neuro-immune axis. Several factors secreted from the immune cells inhibit colorectal afferents in healthy individuals, and loss of this inhibition may lead to hypersensitivity and other IBS symptoms. In their recent study, Hughes et al determined the immune cell types responsible for opioid secretion in humans and whether their expression was altered in patients with IBS. ${ }^{25} \beta$-Endorphin was identified predominantly in monocyte or macrophages relative to $\mathrm{T}$ or B cells in human peripheral blood mononuclear cells and colonic lamina propria. Noteworthy, monocyte-derived 
$\beta$-endorphin levels and colonic macrophage numbers were lower in IBS patients than healthy subjects, which means weaker inhibition of colonic afferent endings. Hughes et al thus showed that altered immune function contributes toward visceral hypersensitivity in IBS. ${ }^{25}$

In 2013, the same group proved that sensory neuroimmune interactions differ between IBS subtypes. ${ }^{26}$ Supernatants from IBS-D patients caused mechanical hypersensitivity of mouse colonic afferent endings, which was reduced by infliximab. In case of constipation-predominant IBS, the supernatants had no such effect, but occasionally elevated basal discharge. Several cytokines, IL-1 $\beta$, IL-6, IL-10, and TNF- $\alpha$, were elevated in supernatants from IBS patients, and levels correlated with pain frequency and intensity in those patients. TNF- $\alpha$ most effectively caused mechanical hypersensitivity; the effect was blocked by a TRPA1 antagonist. To summarize, the results of this study showed that IBS patient subgroups would benefit from selective targeting of the immune system. ${ }^{26}$

In 2013, Dove et al conducted the first randomized, double-blind, placebo-controlled Phase II clinical trial on eluxadoline, in which 807 patients were randomly assigned to groups that received either oral placebo or $5,25,100$, or $200 \mathrm{mg}$ oral eluxadoline twice daily for 12 weeks. ${ }^{27}$ The primary end point was clinical response at week 4 , defined by a mean reduction in daily pain score from baseline of $\geq 30 \%$, and of at least 2 points on $0-10$ scale, as well as a stool consistency score of 3 or 4 on the Bristol Stool Scale (1-7) for at least $66 \%$ of daily diary entries during that week. This study showed that significantly more patients receiving 25 $(12.0 \%)$ or $200 \mathrm{mg}(13.8 \%)$ eluxadoline met the primary end point of clinical response (after 4 weeks of treatment) than patients given placebo $(5.7 \% ; P<0.05) .{ }^{27}$ Dove et al concluded additionally that patients receiving eluxadoline at a dose of 100 and $200 \mathrm{mg}$ also had greater improvements in bowel movement frequency and urgency, global symptoms, quality of life, and adequate relief assessments $(P<0.05)$. Additionally, patients receiving 100 (28.0\%) or $200 \mathrm{mg}$ $(28.5 \%)$ eluxadoline were significantly more likely than those receiving placebo $(13.8 \% ; P<0.005)$ to meet the US Food and Drug Administration response end point during the full 12 weeks of the study. It was also found that eluxadoline was well tolerated, with a low incidence of constipation. ${ }^{27}$

In 2015, Chey et al conducted a randomized, doubleblind, long-term Phase III trial to compare eluxadoline 75 or $100 \mathrm{mg}$ twice daily and placebo. ${ }^{28}$ In their study, a composite clinical response (decrease of daily worst abdominal pain and British Stool Scale scores in weeks 1-12 and weeks 1-26, respectively) was evaluated. The study showed that the composite response was significantly higher after treatment with eluxadoline vs placebo over the weeks 1-12 (23.9\% and $25.1 \%$ for eluxadoline 75 and $100 \mathrm{mg}$, respectively, vs $17.1 \%$ for control; $P=0.014$ and 0.004 , respectively). During the 1- to 26-week period, the response to eluxadoline (75 mg twice daily) vs placebo was also significantly higher (29.3\% vs $19.0 \% ; P<0.001) .{ }^{28}$ Post hoc analysis showed that both eluxadoline dosages resulted in a significant early (weeks 1-4) composite response of improvement in abdominal pain and stool consistency without significant risk of constipation, and adequate relief in at least six of the initial 12 weeks, which confirms the findings from placebocontrolled Phase II clinical trial conducted by Dove et al, Chey et al, and Lacy et al. ${ }^{27-29}$

In another randomized, double-blind, Phase III international trial, Andrae et al showed that two eluxadoline dosages (75 and $100 \mathrm{mg}$ ) led to an early higher composite response (period with no worsening of symptoms or rebound; eg, diarrhea, abdominal pain) than placebo over weeks $1-12$ (28.9\% and $29.6 \%$ for 75 and $100 \mathrm{mg}$, respectively, vs $16.2 \%$ for placebo; both $P<0.001) .{ }^{30}$ The use of both dosages resulted in the significant response stability in the long-term course (weeks 1-26). ${ }^{29,30}$ Furthermore, Andrae et al observed that administration of eluxadoline at 75 and $100 \mathrm{mg}$ was associated with a significant improvement in health-related quality of life vs placebo. ${ }^{30}$

In 2016, Lembo et al published the first meta-analysis about the use of eluxadoline in the treatment of IBS-D. ${ }^{31}$ The study confirmed that eluxadoline reduces symptoms of IBS-D in men and women, with sustained efficacy over 6 months in patients who received the $100 \mathrm{mg}$ dose twice daily. ${ }^{31}$

\section{Side effects of eluxadoline treatment}

Eluxadoline is not free of side effects - the most common is constipation which occurs during treatment with both dosages, 75 and $100 \mathrm{mg}$, and concerns $\sim 5 \%$ of patients treated with eluxadoline. ${ }^{17,29-31}$ In some trials, constipation occurred within the first 2 weeks from the beginning of therapy; however, it had similar scores to those for placebo treatment. Noteworthy, severe constipation has been registered by $<1 \%$ of patients. Nevertheless, eluxadoline has better safety and compliant side effect profile (eg, constipation) compared to pure $\mu$-opioid receptor agonists (eg, loperamide). ${ }^{27,28}$

In addition, $3 \%-5 \%$ of the patients noted upper respiratory tract infections, which are probably incidental. ${ }^{27-29}$ Other, less frequent adverse events were registered in $<2 \%$ of treated patients. These included vomiting, abdominal distension, flatulence, respiratory complaints (nasopharyngitis, bronchitis), 
dizziness, skin rash, increased alanine aminotransferase levels, fatigue, and viral gastroenteritis. ${ }^{28-31}$

Old age ( $\geq 65$ years) could also be a risk factor of side effects during treatment with eluxadoline. For example, higher incidence of adverse events (66\% vs 59\%), serious adverse events ( $9 \%$ vs 4\%), and specifically, gastrointestinal adverse events (39\% vs $28 \%$ ) vs younger subjects was reported. Altered pharmacokinetics of eluxadoline in older patients is probably the cause..$^{30,31}$

As eluxadoline is a $\mu$-opioid receptor agonist, it can induce sphincter of Oddi spasm, particularly in patients who received cholecystectomy. ${ }^{17}$ Trials showed that sphincter of Oddi spasm developed in $0.2 \%$ and $0.8 \%$ of patients treated with eluxadoline 75 and $100 \mathrm{mg}$, respectively, with $80 \%$ occurrence within the first week of treatment. Because of this, eluxadoline should not be taken in case of blockage of the gallbladder or the sphincter of Oddi, or a history of pancreatitis. Onset of acute pancreatitis during treatment with eluxadoline was reported in $0.2 \%$ of patients with a subsiding elevated alcohol intake. ${ }^{27,28}$

Finally, eluxadoline may cause systemic side effects. The reason for these is modulation of opioid receptors in the central nervous system. Euphoria has been reported after eluxadoline administration by up to $0.2 \%$ of patients. Notably, a drunken feeling was observed in $\sim 0.1 \%$ of patients. ${ }^{17,30,31}$

Nevertheless, the percentage of systemic adverse effects due to eluxadoline is lower than in the case of other opioid receptor agonists (eg, oxycodone), as reported in the studies on recreational opioid-experienced subjects, conducted by the US Food and Drug Administration. ${ }^{15,17}$

Sometimes, the usage of constipating drugs by patients with IBS-D may lead to fatal adverse events, like in the case of alosetron mis-prescription. Alosetron has an antagonist action at the 5-HT3 receptors distributed in the enteric nervous system of the gastrointestinal tract. It was withdrawn in the year 2000 following the association with serious life-threatening gastrointestinal adverse effects. ${ }^{15}$ In contrast, none of the serious complications arising from constipation (obstruction, perforation, impaction, toxic megacolon, secondary colonic ischemia, death) was observed for eluxadoline.

\section{Conclusion}

In daily practice, the treatment of IBS is difficult and may take a long time, which may be in part due to the multifactorial cause of the condition. Further studies are therefore needed to clarify the pathophysiologic mechanisms that contribute to the development of IBS-D and help the design of new treatment strategies.

Eluxadoline seems to be a very promising molecule. Due to the alleviation of abdominal pain and diarrhea, eluxadoline can significantly improve patients' quality of life. ${ }^{25}$ Because of the good clinical profile and very few side effects, eluxadoline may soon become one of the most efficient and widely used drugs for the treatment of IBS-D.

\section{Acknowledgments}

This work was supported by the Medical University of Lodz (503/1-156-04/503-01 to JF) and National Science Center (2015/17/N/NZ5/00677 to ASW; UMO-2013/11/B/ NZ7/01301 and UMO-2014/13/B/NZ4/01179 to JF).

\section{Disclosure}

The authors report no conflicts of interest in this work.

\section{References}

1. Fass R. Functional heartburn: what it is and how to treat it. Gastrointest Endosc Clin N Am. 2009;19(1):23-33.

2. Stark D, van Hal S, Marriott D, et al. Irritable bowel syndrome: a review on the role of intestinal protozoa and the importance of their detection and diagnosis. Int J Parasitol. 2007;37(1):11-20.

3. Chey WD, Kurlander J, Eswaran S. Irritable bowel syndrome: a clinical review. JAMA. 2015;313:949-958.

4. Halland M, Saito YA. Irritable bowel syndrome: new and emerging treatments. BMJ. 2015;350:1622.

5. Soares RL. Irritable bowel syndrome: a clinical review. World $J$ Gastroenterol. 2014;20:12144-12160.

6. Wouters MM, Vicario M, Santos J. The role of mast cells in functional GI disorders. Gut. 2016;65(1):155-168.

7. Longstreth GF, Thompson WG, Chey WD, et al. Functional bowel disorders. Gastroenterology. 2006;130:1480-1491.

8. Schwille-Kiuntke J, Enck P, Polster AV, et al. Postinfectious irritable bowel syndrome after travelers' diarrhea - a cohort study. Neurogastroenterol Motil. 2015;27(8):1147-1155.

9. American College of Gastroenterology Task Force on Irritable Bowel Syndrome; Brandt LJ, Chey WD, Fox-Orenstein AE, et al. An evidence-based position statement on the management of irritable bowel syndrome. Am J Gastroenterol. 2009;104 Suppl 1:S1-S35.

10. Yawn BP, Lydick E, Locke GR, et al. Do published guidelines for evaluation of irritable bowel syndrome reflect practice? $B M C$ Gastroenterol. 2001;1:11.

11. Dothel G, Barbaro MR, Boudin H, et al. Nerve fiber outgrowth is increased in the intestinal mucosa of patients with irritable bowel syndrome. Gastroenterology. 2015;148(5):1002-1011.

12. Peery AF, Dellon ES, Lund J, et al. Burden of gastrointestinal disease in the United States: 2012 update. Gastroenterology. 2012;143: 1179-1187.

13. Ford AC, Moayyedi P, Lacy BE, et al. American College of Gastroenterology monograph on the management of irritable bowel syndrome and chronic idiopathic constipation. Am J Gastroenterol. 2014; 109 Suppl 1:S2-S26.

14. Pimentel M, Lembo A, Chey WD, et al. Rifaximin therapy for patients with irritable bowel syndrome without constipation. NEngl J Med. 2011; 364:22-32.

15. FDA approves two therapies to treat IBS-D. Available from: http:// www.fda.gov/NewsEvents/Newsroom/PressAnnouncements/ ucm448328.htm. Accessed June 1, 2015. 
16. Actavis announces FDA acceptance for filing of NDA for eluxadoline. Available from: http://www.prnewswire.com/news-releases/ actavis-announces-fda-acceptance-for-filing-of-nda-for-eluxadoline273557591.html. Accessed June 1, 2015.

17. FDA approves Viberzi (eluxadoline) for irritable bowel syndrome with diarrhea (IBS-D) in adults. Available from: http://drugtopics. modernmedicine.com/drug-topics/news/fda-approves-eluxadolinetreat-ibs-d-adults. Accessed June 1, 2015.

18. Liao D, Lin H, Law PY, Loh HH. Mu-opioid receptors modulate the stability of dendritic spine. Proc Natl Acad Sci U S A. 2005;102(5): 1725-1730.

19. Wood JD, Galligan JJ. Function of opioids in the enteric nervous system. Neurogastroenterol Motil. 2004;16:17-28.

20. Kurz A, Sessler DI. Opioid-induced bowel dysfunction: pathophysiology and potential new therapies. Drugs. 2003;63:649-671.

21. Fujita W, Gomes I, Dove LS, et al. Molecular characterization of eluxadoline as a potential ligand targeting mu-delta opioid receptor heteromers. Biochem Pharmacol. 2014;92:448-456.

22. Land BB, Bruchas MR, Lemos JC, et al. The dysphoric component of stress is encoded by activation of the dynorphin kappa-opioid system. J Neurosci. 2008;28(2):407-414.

23. Varga EV, Navratilova E, Stropova D, et al. Agonist-specific regulation of the delta-opioid receptor. Life Sci. 2004;76(6):599-612.

24. Gebhart GF, Su X, Joshi S, et al. Peripheral opioid modulation of visceral pain. Ann N Y Acad Sci. 2000;909:41-50.
25. Hughes PA, Moretta M, Lim A, et al. Immune derived opioidergic inhibition of viscerosensory afferents is decreased in irritable bowel syndrome patients. Brain Behav Immun. 2014;42:191-203.

26. Hughes PA, Harrington AM, Castro J, et al. Sensory neuro-immune interactions differ between irritable bowel syndrome subtypes. Gut. 2013; 62(10):1456-1465.

27. Dove LS, Lembo A, Randall CW, et al. Eluxadoline benefits patients with irritable bowel syndrome with diarrhea in a phase 2 study. Gastroenterology. 2013;145:329.e1-338.e1.

28. Chey WD, Dove S, Andrae D, et al. Eluxadoline demonstrates sustained efficacy for the treatment of diarrhea-predominant irritable bowel syndrome in phase 3 clinical trials. Gastroenterology. 2015;148: S70-S71.

29. Lacy BE, Dove S, Andrae D, et al. Robustness of eluxadoline for the treatment of irritable bowel syndrome with diarrhea: results from phase 3 composite endpoint assessments [abstract no. Su1378]. Gastroenterology. 2015;148:S491.

30. Andrae D, Buono JL, Covington PS. Effect of eluxadoline on healthrelated quality of life in adults with irritable bowel syndrome with diarrhea: results from two randomized, double-blind, placebo controlled phase 3 trials. Gastroenterology. 2015;48:S494.

31. Lembo AJ, Lacy BE, Zuckerman MJ, et al. Eluxadoline for irritable bowel syndrome with diarrhea. $N$ Engl J Med. 2016;374(3):242-253.
Therapeutics and Clinical Risk Management

\section{Publish your work in this journal}

Therapeutics and Clinical Risk Management is an international, peerreviewed journal of clinical therapeutics and risk management, focusing on concise rapid reporting of clinical studies in all therapeutic areas, outcomes, safety, and programs for the effective, safe, and sustained use of medicines. This journal is indexed on PubMed Central, CAS,

\section{Dovepress}

EMBase, Scopus and the Elsevier Bibliographic databases. The manuscript management system is completely online and includes a very quick and fair peer-review system, which is all easy to use. Visit http://www.dovepress.com/testimonials.php to read real quotes from published authors.

Submit your manuscript here: http://www.dovepress.com/therapeutics-and-clinical-risk-management-journal 